\title{
The People Are Missing: Cramped Space, Social Relations, and the Mediators of Politics
}

\author{
Nicholas Thoburn ${ }^{1}$
}

Published online: 5 September 2016

C The Author(s) 2016. This article is published with open access at Springerlink.com

\begin{abstract}
This article investigates the place of social relations in Deleuze and Guattari's figure of 'cramped space', a figure integral to their 'minor politics'. Against social and political theories that seek the source of political practice in a collective identity, the theory of cramped space contends that politics arises among those who lack and refuse coherent identity, in their encounter with the impasses, limits, or impossibilities of individual and collective subjectivity. Cramped space, as Deleuze puts it, is a condition where 'the people are missing'. This is not, however, a condition of asocial isolation, but one full of social relations; the loss of identity is a condition comprised only of social relations. The ramifications of this thesis are here explored through Marx's critique of citizenship, the socio-historical conjuncture of cramped space in relation to the 'communization' problematic, and the Palestinian mediator of sumud.
\end{abstract}

Keywords Deleuze and Guattari $\cdot$ Minority $\cdot$ Citizen $\cdot$ Communism $\cdot$ Palestine

It is a commonplace in social science to seek the source of political practice in a collective identity - the identity of a people, nation, class, or minority - as it comes to articulate itself, or its grievances, in the social realm. This commonplace is upended in Deleuze and Guattari's figure of 'cramped space', which contends that politics arises among those who lack and refuse coherent identity, in their encounter with the impasses, limits, or impossibilities of individual and collective subjectivity. Cramped space, as Deleuze (1989, p. 216) puts it, is a condition where 'the people are missing'.

The notion of cramped space was integral to my 2003 book Deleuze, Marx and Politics, which sought to develop a concept of 'minor politics' from intersections between Marx's formulation of the proletariat and Deleuze and Guattari's theory of 'minority' (Thoburn 2003). Prompted by this journal special issue on global mobility under cramped conditions to reflect further on these themes, I aim here to deepen and expand the concepts of cramped space and minor politics, proceeding in part as response to two criticisms of these concepts from the

Nicholas Thoburn

n.thoburn@manchester.ac.uk

1 Department of Sociology, University of Manchester, Oxford Road, Manchester M13 9PL, UK 
realms of political philosophy and social movement activism: first, that minor politics champions 'minority identities' in an undifferentiated social flow (a critique made by Peter Hallward); second, from a quarter more sympathetic to the thesis, that I cede too much agency to hostile social forces and risk 'privileging the most cramped sector, the most oppressed' (The Free Association). While these critiques draw seemingly opposite conclusions - that the concept of minor politics entails either too much or too little autonomy-they both pertain to the nature of the relationship between cramped space and social relations. This is a relationship that is central to this special issue's intervention - and to contemporary politics more broadly - in thinking the politics of global social relations in terms of constraint as much as of flow, or, more accurately, in the constraints that are intrinsic to flow.

I hence concentrate here on the place in cramped space of social relations, and I do so also with the aim to specify the historicity of the concept, as it pertains to the demise of the working class subject of Fordism and the critical appropriation of that demise. Developing these points raises the question of what kind of collectivity arises in cramped space, if here there is no individual or collective identity, a point that I pursue in relation to the dynamics of minority 'mediators'. This article is primarily theoretical, but my discussion of mediators leads into consideration of a particular example of politicised cramped space, in the Palestinian mediator of 'sumud' as explored in research on Palestinian minor politics by Lena Meari. I would note that while the structure of this article is loosely based on responses to and uses of my Deleuze, Marx and Politics, my aim is not to defend that book but to develop through discussion analytic points of political pertinence to the social experience and theory of cramped space.

\section{The Social Relations of Majority and Minority}

Deleuze and Guattari's figure of cramped space was first proposed in their 1975 book on Kafka, as a component of their concept of 'minor literature'. It seeks to conceptualise the way that minorities experience the interplay between the individual and the social, the personal and the political - or, better, how the minority experience is characterised by the breakdown of these boundaries - and the ramifications of this breakdown across a range of linguistic, aesthetic, and political phenomena. The argument is made in contrast to the experience of 'majority'. Majority describes a system of identities that are constituted in and nurtured by social relations, by the self-bolstering security that class, gender, race, sexuality, citizenship, age, language, and so forth, confer upon those who inhabit the privileged position in these social configurations. Here, there is a fit between majority identity and the social that, paradoxically, gives majority identity autonomy from the social. For insofar as social relations serve to facilitate and bolster majority identities in this way, the social appears at a remove, an inconsequential background for the free play of associating individuals. Hence, Deleuze and Guattari (1986, p. 17) write of the majority condition that 'the individual concern (familial, marital, and so on) joins with other no less individual concerns, the social milieu serving as a mere environment or a background'. Though they do not reference Marx at this point, there is a remarkable consonance here with his formulation of the bourgeois polity, in consideration of which we can start to challenge the self-satiated security of the majority individual.

In his 'On the Jewish Question', a text also concerned with the political nature of minority conditions and their interplay with majority standards, Marx shows how the bourgeois individual of modern civil society - the 'citizen', the subject of the 'rights of man', the 
'possessive individual' as we know it since C. B. MacPherson-is premised on an opposition between individual and social existence. This time, the social, that which facilitates and bolsters the individual, is experienced with a little variation, less as inconsequential background than as nagging threat, as that which impinges on the primary autonomy of the individual - and of course we can think forward to Margaret Thatcher's (1987) protestations against 'society' ('There is no such thing!') as an archetypical instance of this sensibility in neoliberal times. The real delimiting power, however, is the social form of the individual itself, for Marx reveals the freedom that is conferred by bourgeois identity to be a condition of constraint. The threat to the good life, as it were, is not the social but the 'liberty', in Marx's (1975a, p. 230) cutting phrase, of the 'confined individual, confined to himself'. The individual, a product of capitalist social relations that masquerades as its ground and cause, constrains sociality ('species being' or 'communal being', in Marx's parlance) into the isolated subject of private property:

In the rights of man it is not man who appears as a species-being; on the contrary, species-life itself, society, appears as a framework extraneous to the individuals, as a limitation of their original independence. The only bond which holds them together is natural necessity, need and private interest, the conservation of their property and their egoistic persons (p. 230).

Bourgeois politics partakes of and enforces this structure, such that social being experiences a double degradation, not only excised from the confined and partial individual, but reduced to a mere support for the latter: 'the [political] sphere in which man behaves as a communal being [Gemeinwesen] is degraded to a level below the sphere in which he behaves as a partial being' (p. 231). To recover that social as the condition of politicised being, Marx turns to those who are excluded from the citizen. For the bourgeois subject and its claimed universal community, as Marx saw it, was not only a partial and isolated identity, it was also available only to a particular class, race, and gender. That is to say, it was structured on a series of exclusions, as the tenuous relation to property - or being property - meant that slaves, racialised others, women, and the working class were excised from the self-identity of the citizen and its supposedly universal community, their social conditions of being privatised or naturalised, deemed outside the realm of the political. And yet for Marx it is precisely the politicisation of these excluded social relations that constitutes politics proper, the ground of the 'social' revolution rather than the 'merely political revolution, the revolution which leaves the pillars of the building standing' (Marx 1975b, p. 253). Hence, in an argument replete with paradoxes, it was the excluded who bore the universal, in that their exclusion undermined the purported universalism of the bourgeois subject, and that their politics necessarily brings forward concrete social relations and not abstract identity as its substance, the social relations where one finds the 'real movement which abolishes the present state of things' (Marx and Engels 1974, pp. 56-7).

It is on this front of the excluded or marginalised and their experience of social relations that Deleuze and Guattari develop their concept of minority, though under the changed circumstances of the extended reach of formal citizenship that has (unevenly) accompanied modernity since Marx's time. Here, the relation between the individual and the social takes a rather different form than it does for majorities. Minorities are those who are positioned unfavourably in relation to privileged poles of class, gender, race, and so on, such that social relations no longer facilitate coherent and autonomous identity, even when citizenship is granted. For Black Americans, to take an example recently pushed into global consciousness by the US Black Lives Matter movement, formal citizenship offers no security or coherent identity amidst the different but 
overlapping social constraints of unemployment, spatial segregation, prison, and police murder with impunity, for these constraints are embedded within social relations whose workings are so impervious to challenge from the realms of abstract rights and legal equalities that one must ask whether civil society is in fact grounded upon their perpetuation. To draw from Frank B. Wilderson (2003), in the gratuitous anti-Black violence of the US police against populations newly superfluous to the requirements of capital, and in the civil debarment of Black people through mass incarceration in the for-profit prison network, the foundational exclusion constitutive of bourgeois universality - the exclusion of the slave: not possessor of property but property possessed, subject to violence without reason or restraint - is carried over as a condition of the perpetuation of civil society under crisis conditions.

Returning to Deleuze and Guattari, in the minority condition we see, then, that the social milieu ceases to be mere background and floods individual experience, rendering identity unstable or 'impossible', as life becomes a tangle of conflicting imperatives and constraints without a selfcoherent centre of identity. It is the condition of cramped space, where 'the private affair merges with the social—or political—immediate' (Deleuze and Guattari 1986, p. 17; Deleuze 1989, p. 218). As with Marx, this is the properly political experience. Unlike the more or less inconsequential 'individual concerns' of majority politics - where no political intrigue is 'specifically indispensible or absolutely necessary but all become as one in a large space' - cramped space 'forces each individual intrigue to connect immediately to politics', for, without an autonomous identity, even the most personal, intimate situation is composed of social relations and experienced as such (Deleuze and Guattari 1986, p. 17). Social life presents boundaries or impasses rather than enabling possibilities or clear options; there is no identity that is not impossible to inhabit unproblematically. Yet, the impossibility of activity is matched with the impossibility of doing nothing if life is to be lived. As in Beckett's (1979, p. 382) formula, 'I can't go on, I'll go on', politics thus becomes a process of 'tracing a path between impossibilities', in Deleuze's (1995, p. 133) words — or better, of tracing a path amidst, with, and against impossibilities.

Before proceeding, I want to fend off three possible miss-readings that the term cramped space might otherwise encourage. First, though it clearly has a spatial dimension, the way the minority condition is constituted in relation to the partitions and borders that traverse geosocial territory (the mobile borders of the nation state, for instance, where spatial partition is a primary determinant of the differential partition of citizenship rights), cramped space is a condition of social existence in the round. It involves all the dimensions of social being, including temporal qualities, affective conditions, linguistic forms and procedures, technologies, sensory and aesthetic paradigms, and so on. Second, the cramped condition might be an experience of circumscribed confinement-being bound to the home, incarcerated in an immigration detention centre or a prison cell-but the concept seeks to describe not confinement as such but immanence to the social, to the multitude of constraints and commands associated with lives interlaced with and buffeted by global social relations. Hence, undocumented migration - where constraint and flow are interlacedpresents a paradigmatic minor experience. Third, for all its loss of identity and immanence to social relations, cramped space is not a loss of particularity, quite the contrary. The mesh of complex and contradictory social relations in every particularity produces experiences much more various and contingent than the formatted differences of the major individual, such that it is only in and through particular and situated differences that the political treatment of social life can be grasped and affirmed. In cramped space, 'The individual concern thus becomes all the more necessary, indispensable, magnified, because a whole other story is vibrating within it' (Deleuze and Guattari 1986, p. 17). 


\section{Minority, Capital, Proletariat}

I have argued that minorities are constituted by and interlaced with social relations. It is on this condition that the politics of cramped space is founded - quite the opposite of the critique made by Hallward (2006, pp. 185, 162), that in this and associated readings of Deleuze one finds only 'minor identities', 'evanescent' and 'indifferent to the politics of this world'. Specifying this point, Hallward argues further that Deleuze's politics offers little to grasp contemporary 'mechanisms of exploitation and domination' and relations of 'conflict and solidarity' (p. 162). I will address these later points through another critique of the minor politics thesis, now specifically with regard to the figure of cramped space.

If Hallward finds in Deleuze and Guattari's concept of minority too much autonomy from the mechanisms of exploitation, the critique of my reading made by the Free Association is that there is too little. Consideration of their argument assists in delineating further the specific role of capitalism in the theory of cramped space and of the historical conjuncture to which the concept of minority pertains. The Free Association frame my interpretation of cramped space as a concern with the 'dangers and limits' imposed by capital and, insofar as they see cramped space as a useful political concept, they separate the condition from its direct relation to capital (for it to become a self-possession of social movements, an internal dynamic, as I take up later). To do otherwise, they argue, is to undermine the 'active' quality of social movements and to revert to a politics that seeks and affirms a political constituency of those who are most oppressed. In their words:

Thoburn uses this [concept of cramped space] to argue against any idea that we exist in a state of plenitude. Rather, we need to pay attention to the limits that capital displaces onto us. While we respect the need to be aware of dangers and limits, we think it is very important always to emphasise that we are active and capital is reactive. Perhaps we are overly sensitive to this issue, but we believe that any other emphasis risks a return to identifying and privileging the most cramped sector, the most oppressed people, which we believe would be a terrible mistake. Cramped space for us is something we create, something we have inside ourselves, not something capital does to us. As Deleuze goes on to say: 'A creator's someone who creates their own impossibilities, and thereby creates possibilities' (The Free Association 2005, p. 576).

Cramped conditions certainly carry many dangers and oppressions, but as I hope is apparent from the discussion thus far, the concept of minority cramped space aims not to cautiously warn of these. Rather, the concept seeks to grasp the minority condition of being interlaced with social relations and to assert these social relations in their multiform variety and complexity — not social movement collectivity — as the substance of politics. Contrary to the Free Association's separation of an active and autonomous social movement 'we' from capital, the concept of cramped space teaches that minorities have no autonomy, that capitalist social relations are not extraneous to a collective subject, but the very substance of collective being, where the subject is missing - the 'we', at most fragmented, buffeted, and unstable, only emerges in the practical critique of the capitalist conditions of its being. This is not to disempower minorities or to be excessively cautious. Against the degraded politics of the bourgeois polity, where social relations are a mere background, it is precisely in the loss of autonomy that one arrives at a concept and experience of politics that is truly adequate to the complexities of contemporary social life - even as, or because, this is lived as a field of impasse and impossibility. 
Still, perhaps the concept of minor politics privileges those who are most cramped, most oppressed? This is not the aim, for the immanence of minority conditions with social relations is conceived of as the basis of universality. As we saw with Marx, the abstract universal of the bourgeois subject was revealed to be a restricted particular, while the excluded particulars were bearers of the universal - both due to their exclusion and to the social, not mere political, nature of this exclusion and the solutions adequate to it. Hence the fundamental significance of Deleuze and Guattari's alignment of minority with Marx's concept of universality, the proletariat. They add a proviso, though this is less a distancing tactic than an attempt to foreground the self-abolition that is integral to Marx's concept (as I pick up below):

The power of minority, of particularity, finds its figure or its universal consciousness in the proletariat. But as long as the working class defines itself by an acquired status, or even by a theoretically conquered State, it appears only as 'capital', a part of capital (variable capital), and does not leave the plan(e) of capital (Deleuze and Guattari 1988, p. 472).

\section{Ours Is the Age of Minorities}

Thinking through the consequences of the relation between the cramped space of minority and the class condition of the proletariat necessitates consideration of the specific historical conjuncture to which Deleuze and Guattari's concept pertains. Deleuze and Guattari first articulate the concept à propos Kafka's socio-linguistic condition of a Prague Jew writing in German amidst the breakdown of the Habsburg Empire, the disorienting semantic and textual qualities of Kafka's writing handling this quintessentially modern experience of geopolitical reconfiguration and migratory flux. But as the concept of minority is developed in A Thousand Plateaus, it tracks the capitalist transformations of the late 1970s. 'Ours is becoming the age of minorities,' Deleuze and Guattari (1988, p. 469) write here, with specific reference to structural developments in capitalist accumulation associated with globalisation and post-Fordism. The imperative of capitalist accumulation to set and overcome limits (that is, to delimit and exhaust territories and social forms, while moving beyond those to new territories and forms, in combined and uneven development) has produced an ever more fragmented, variegated, and mutable patchwork of unequal exchange, exploitation, and poverty, where 'peripheral zones of underdevelopment' become constitutive features of the 'center' (p. 469). Global flows of migration are a central dimension of this condition, as is the breakdown of the identity structures of Fordism - where, in its normative majority form, 'subjection remained centred on labour' - such that populations are henceforth 'abandoned to erratic work (subcontracting, temporary work, or work in the underground economy), and their official subsistence is assured only by State allocations and wages subject to interruption' (p. 469). Such tendencies have of course taken leaps and bounds in the 35 years since A Thousand Plateaus was published, as precarity and punitive workfare have become labour market norms and work has withdrawn from the circuit of social reproduction for significant sectors of the global population - with state brutality filling out the vacated space, as has been laid bare in the USA by the Ferguson and Baltimore riots (2014 and 2015) against the murderous structural racism of the police (see Endnotes 2015).

In so locating the socio-historical conjuncture of the concept of minority, Deleuze and Guattari draw from the Italian Marxist currents of operaismo and autonomia. It is momentary but at key points, with Deleuze and Guattari referencing Antonio Negri on the rise of 
precarious work and Yann Moulier-Boutang on the breakdown of the majority subject of traditional Marxism - 'the national Worker, qualified, male and over thirty-five' — and quoting Mario Tronti to assist their case for considering the proletariat as a class of self-abolition: 'To struggle against capital, the working class must fight against itself insofar as it is capital' (Moulier-Boutang, cited in Deleuze and Guattari 1988, p. 469; Tronti, cited in ibid., p. 571). And yet, Deleuze and Guattari share less with this critical scene than is often thought. For its signal thesis of the primacy of struggles in determining capitalist development opens the possibility — as especially evident in Hardt and Negri's Empire trilogy — of conceptualising the working class and capital as independent terms, the latter becoming merely the external apparatus of capture of an autonomous subjective content (Thoburn 2003). Hence, if one is to draw out the socio-historical juncture of minority in a manner that foregrounds not autonomy but cramped space, it can be more productive to look elsewhere, which I do here, turning to the 'communization' problematic in contemporary communist thought, especially as developed in the journals Théorie Communiste and Endnotes.

\section{The Impasse of Workers' Identity}

The theory of communization proceeds from the argument I touched upon above, that through the 1970s the dominant class form of the twentieth century - a collective workers' identity whose subjection was centred upon labour - went into terminal crisis. It was a class form that the French journal Théorie Communiste calls 'programmatism', where communist futures were to be founded on social relations formed in present modes of struggle, such that communism was the affirmation of an existent proletarian subjectivity. In their words:

programmatism ... is a theory and practice of class struggle in which the proletariat finds, in its drive toward liberation, the fundamental elements of a future social organisation which become the programme to be realised. This revolution is thus the affirmation of the proletariat, whether as a dictatorship of the proletariat, workers' councils, the liberation of work, a period of transition, the withering of the state, generalised self-management, or a 'society of associated producers' (Théorie Communiste 2008, p. 155).

Marx in his more visionary moments pointed beyond this framework of programmatism, positing the proletariat, along the lines picked out above, as the class not of self-affirmation but of self-abolition. It is a formulation, as in this example from The Holy Family, that crackles against his time and ours: 'The proletariat ... is compelled as proletariat to abolish itself and thereby its opposite, private property, which determines its existence, and which makes it proletariat. It is the negative side of the antithesis, its restlessness within its very self, dissolved and self-dissolving private property' (Marx and Engels 1975, p. 36). But up until the 1970s, the nature of the class relation, or the capitalist organisation of production and reproduction, was such that the working class was socially determined to recognise itself as a positive identity — amassed and concentrated in factories and industrial cities, and affirmed as such first through its independent institutions, by which it gained organisational power and social respectability, and later through its claim on citizenship, in its political and legal recognition within the social democratic state.

Under these conditions, the programme of revolution was carried within the working class on the basis of its role as provider of labour. This is the transhistorical understanding of labour that was intrinsic to the workers' movement, labour 'that constitutes the social world and is the source of all social wealth', as Moishe Postone's (1996, p. 8) critique characterises it. And this is the crux of the 
problem with the class identity of the workers' movement. In so taking an historically specific feature of capitalism alone to be a universal human condition, the resultant politics necessarily took its field of contestation to be distribution of the products of labor and not critique and abolition of labor and its subject, a 'new mode of politically administering and economically regulating the same industrial mode of production to which capitalism gave rise' (p. 9).

We hence see that the apparent autonomy of the working class from capital, as established in the institutions of the workers' movement, turns out to have been the specific form of its integration with capital, as its institutions and motivations fashioned an affirmative subject out of that which was imposed by capital, and so all too easily came to merge with the motivations of capitalist development. To affirm working class autonomy - with real gains in the quality of life, no doubt - was simultaneously to affirm the capital-labour relation. As such, the workers' movement 'loses its way' not so much in being insufficiently revolutionary, but in having a content that was insufficiently differentiated from that of capitalist revolution (Théorie Communiste 2008, p. 156). Of this tendency, the state-led and totalitarian industrialisation of the Soviet Union, which far exceeded in rapidity what market capitalism could have achieved, is the most acute moment, Bolshevik 'counterrevolution' as 'the accomplishment against [proletarians] of their revolution' (p. 174). And here we confront the structural impasse of the workers' movement, whereby 'the proletariat seeks to liberate against capital its social strength which exists in capital,' and exists there only (p. 157). Even in its more radical variants that come after 1917 as a challenge to the counter-revolution of Bolshevism, communism was still formulated as a question of organizational form - most emblematically, the workers' council versus the Leninist party - rather than as practical critique of the content of work and capitalist social relations, or, it is the same thing, of itself as subject of labour (Dauvé 1997).

Moving from the critique of programmatism to the periodisation of class today, for Théorie Communiste it is only now that this horizon of the affirmation of labour and the positivity of working class identity can be overcome, after the cycle of struggles of the late 1960s and early 1970s (where the 'refusal of work' within the sphere of labour, and struggles over social reproduction among women, racialised groups, and others structurally marginalised by that sphere, signalled the crisis of the programmatic affirmation of workers' identity) and the subsequent restructuring through globalisation and financialisation. This is in large measure because what Marx called the 'real subsumption' of labour in capital has reached a stage where capital no longer needs an affirmative subject of labour-having found the rigidities of national labour markets, the welfare state, collective wage bargaining, and so forth, to be obstacles to valorisation - and is instead increasingly self-positing. As Endnotes (2008) develop the point, there is simply no ground upon which to found a positive and enduring workers' identity or to project its coming into being as a revolutionary subject. The global fragmentation of labour; the long-term decline in real wages; the move to the heart of the wage relation of flexibility, precarity, and under-unemployment; and the extension of superexploitation and informal work attendant on the tendential rise in superfluous populationsfrom all these comes 'the impossibility of the proletariat to relate to itself positively against capital: the impossibility of proletarian autonomy' (Endnotes 2008, p. 214). In other words, class - the condition of needing to sell one's labour, whether achieved or not, and of being dependent on those whose labour power is enabled by the unpaid work of reproduction - is evacuated of positive identity and becomes increasingly experienced and understood as an external imposition. Hence, when workplace struggles occur today, their aims are largely limited to defending jobs against layoffs, or extracting redundancy payments rather than demanding the right to work, within which neither positive identity nor any real solution to 
the difficulty of self-reproduction is readily found. Their limits are quickly reached, engagement with which - and pushing beyond - may well be the condition of struggles to come.

The point is not of course that identity vanishes. Indeed, the collapse of class as a positive identity witnesses a swarming of identities - grounded in work or not - that are offered and pushed as positive solutions, from the maligned 'white working class' of national populist and far Right discourse, to the entrepreneurial self, with its metabolisation — one part necessity, another part vain hope - of neoliberal regimes of insecurity and competition. We see also instances of a dogged clinging to the self among working class populations riven with precarity and debt, those, paradoxically, for whom the self least coheres, and yet who find themselves without other resource, bereft of supportive social institutions in a social realm encountered as humiliation and betrayal (Silva 2013). Minority, too, has its identity forms, as I touch upon below regarding the depoliticised Palestinian identity co-produced by the Palestinian Authority and the Israeli state. But the limits inherent to these identities could not be more apparent, even in their own terms. Of course, the resultant fragility and instability of identity is not without its own identity-effects, recharging the pursuit of a coherence that ever fails, and with dangerous consequences. But such are the kinds of problems that face a politics that would be adequate to the collapse of workers' identity.

I hope it is clear from this discussion that it is not too much of a leap to say that in the theory of communization we have a socio-historical specification of what Deleuze and Guattari call cramped space, and one that draws out its structural condition, a condition that renders the majority identity of the worker obsolete, impossible to inhabit as a positive and coherent subjective form. And while the broader features and ramifications of Deleuze and Guattari's concept of minority are not at all shared by communization theory, the latter does share the concern to fashion a political theory on the loss and impossibility of identity. If a programme founded upon the affirmation of workers' identity is now passed, communism turns instead on encounters with the limits to identity, on the structural impasses, complicities, and exclusions that condition sectoral identities, social movements, and racialised and gendered groups. Here, the limit is less a boundary that solicits transgression than the immanent horizon of self-overcoming:

The theory of communization alerts us to the limits inherent in ... struggles, and indeed is attentive to the possibilities of a real revolutionary rupture opening up because of, rather than in spite of, those limits.... [I]n any actual supercession of the capitalist class relation we ourselves must be overcome; 'we' have no 'position' apart from the capitalist class relation ... [I]t is a rupture with the reproduction of what we are that will necessarily form the horizon of our struggles (Endnotes n.d., p. 29, 31).

Perhaps this sounds like a betrayal of constituencies in struggle, withholding support from their barely achieved coherence. So let me be clear that to disrupt the identities of struggle in this way is not to be against solidarity, quite the reverse. The overcoming of limits is a solidarity - a terribly fraught endeavour, certainly - that is produced in and through the undoing of the sectoral and minority identities that bind social groups to the conditions they nominally oppose, where the limit is a potential opening to solidarities and social relations that are otherwise structurally curtailed.

\section{Willed Poverty and Minority Mediators}

To condense the preceding discussion, we can say that in the current conjuncture, 'the proletariat is in itself nothing, but a nothing full of social relations' (Théorie Communiste 2006, p. 70). Here, cramped space is not, as it is for the Free Association, a condition that could exist in 
separation from capital, because it is the social experience of capital. And yet, as the Free Association point out, Deleuze (1995, p. 133) does evoke the self-creation of cramped space, to make his point again: 'A creator's someone who creates their own impossibilities, and thereby creates possibilities'. The individualised dimension of this and related passages in Deleuze are I think of limited use; thankfully, they are rarer and less rigorously developed than his analysis of the social and impersonal dimensions of minority production. But there is something important in his formulation here nonetheless, regarding the dynamic of cramped space. For the Free Association, it confirms their understanding of cramped space as a dynamic internal to social movements, where cramped space signifies a self-reflexive moment of forcing a movement's downswing away from calcified identity into intensive experiment, something like a social movement combustion engine that causes a new upswing to burst forth from constraint. But if cramped space cannot be understood as a social movement property separated from capitalist relations, how can one make sense of Deleuze's comment? I see it as attempting to evoke a propulsive critical sensibility, where the structural condition of cramped space is associated also with a certain 'willed poverty', as, in Kafka's words, 'one strives to see [the boundary] before it is there, and often sees this limiting boundary everywhere' (Deleuze and Guattari 1986, p. 17; Kafka, cited in ibid.). In this sense, to create one's own impossibilities is the opposite of selfcreation; rather, it is to expand one's field of perception to the manifold of global social relations that traverse cramped particularity, one's perceptivity to the social disruption of the autonomous self, and, it is the same thing, to continually ward off tendencies to identity, to the seductions of self-affirmation. This is the sensibility of cramped political practice, a persistent deferral of subjective plenitude that forces ever-new critical engagement with social relations. Rather than allow the solidification of particular political and cultural routes, forms, and identities, the 'willed poverty' of cramped space ever serves to draw thought and practice back into a milieu of contestation, argument, and engagement, forcing thought and practice from within the constraints and impossibilities of social relations.

One might conclude from the discussion thus far that there is simply no basis for collectivity in cramped conditions, but that is not the case. Deleuze and Guattari in fact go some way to elaborating the conditions of cramped collectivity, of minority collectivity without identity. I will take up one aspect of this, regarding the role of 'mediators' in cramped space.

The ungrounded ground of the critical interrogation of social relations that we have seen thus far has an expressive and textual dimension. Deleuze and Guattari draw this from Kafka, who sketches an argument in his diaries that minor literatures emerge not in great works of fiction, in the novel, but in 'magazines', in intensive and fragmented expressive milieus characterised by 'liveliness' and 'conflict' (and one cannot but recall in this context Kafka's own inclination toward the literary forms of the short story and aphorism, his three novels remaining incomplete) (Kafka 1999, p. 150). In these marginal mediums and forms, what major literature would view as the social background or 'cellar' - the terrain of everyday concerns, of particular intrigues that lie outside of the legitimate space of writing proper - is drawn up into the foreground of textual and aesthetic production:

There is universal delight in the literary treatment of petty themes whose scope is not permitted to exceed the capacity of small enthusiasms and which are sustained by their polemical possibilities. Insults, intended as literature, roll back and forth. What in great literature goes on down below, constituting a not indispensable cellar of the structure, here takes place in the full light of day, what is there a matter of passing interest for a few, here absorbs everyone no less as a matter of life and death (Kafka 1999, p. 150). 
This 'cellar' of polemics, intrigues, and everyday concerns substitutes for the grand histories or traditions that occupy national literatures, since without a coherent identity or people, a relation to anything that minorities might describe as their history is at most opaque, broken, and uncertain. But this too is a condition of cramped production, since, shorn of the ballast of readymade traditions and collective memories, the intense reworking of social conditions in the present inclines not into the past, of achieved and continuous identity, but into the future. And here minorities $d o$ have a certain agency, or an agency that is adjacent to them - an agency of the mediator. Deleuze writes that critical manoeuvre in cramped space is aided by mediators, which have a catalytic capacity to carry, intensify, and diversify the interrogation of cramped conditions. A mediator can be real, imaginary, animate, or inanimate - a person, an object, plants, animals, myths, a certain discourse, an image, a refrain, or a problem (Deleuze 1995, pp. 125-7). Corresponding to the majority form, Right-wing mediators reflect and confirm established identities, collectivities, and truths - consider the role of an established national flag, a state-fuelled commonsense trope of 'workers and shirkers', the mobilised melancholia of wartime spirit, the weaponised myth, as I will come to shortly, of 'a land without a people for a people without a land'. Deleuze calls these 'direct' mediators, insofar as they are directly indexed to a people and a place (p. 128). They contrast to the 'indirect or free mediators' of the Left, which bear the more fragile quality of cramped minority experience, having no established identities and truths upon which to gain traction, or, put otherwise, relating to established identities and truths only insofar as they seek to overturn them and make visible the oppression or constraint that otherwise remains hidden - it goes some way to explain why the Left has less success in establishing mediators than the Right (p. 128). But in being ungrounded in this way, Left mediators - I would prefer to call them 'minority mediators' or 'communist mediators', to leave behind the Left/Right dichotomy of the bourgeois polity — take on a certain agential quality, a quality pertaining precisely to their indirect nature.

'Indirect' here draws from Deleuze's (1989, p. 148) particular understanding of 'free indirect discourse', a discourse or problem dislodged from any one speaking subject that hence carries a desubjectified and somewhat uncanny quality, its existence between the unstable individual and the missing collective. Such indirect problems endure insofar as they have an inexact correspondence to any particular minority situation, maintaining a structural incompletion, leaving them at once more prone to failure and open to further unfurling as they are taken up in open-ended 'series', in diverse and various conditions (Deleuze 1995, p. 125). This gives the free indirect problem or mediator a bricolage quality; it is a broken, cumulative, processual, and unfinished entity — a 'monster'; it 'has a life of its own: an image that is always stitched together, patched up, continually growing along the way' (Deleuze 1989, p. 150; Deleuze 1997, p. 118). And as this description suggests, it has also a volitional or catalytic capacity. A product of the multiple voices that comprise it, a free indirect mediator, in its quasi-autonomous condition, reacts back upon them to become a cause, as it draws out or induces ideas, practices, associations, affects that are adequate to it, and to its unfurling.

\section{The Palestinian Mediator of Sumud}

I will take one instance of such a free indirect mediator, regarding Palestinian struggles against Israel's brutal regime of settler colonialism. Deleuze not infrequently takes up the Palestinian cause in his discussions of minority and the notion of the 'missing' people, and it features too in his account of mediators. The Zionist project of 'a people without a land for land without a people' constitutes Palestinians as a cramped minority across coordinates that are territorial, economic, historical, geo-political, linguistic, and intimate all at once. This is the Nakba or 'catastrophe' of 
1948, when Israel was founded on the expulsion of $80 \%$ of the existent Palestinian population, and the militarised colonisation and hollowing out of the occupied territories from 1967 (Makdisi 2008; Weizman 2007). In the face of this, Palestinian struggle is, no doubt necessarily, framed as seeking recognition as a people, but it operates on the conditions by which Palestinians are constituted by Israel as an impossibility. As Lena Meari (2014) explores in relation to the concept of minor politics, a significant plank of this struggle has been the mediator of 'sumud', on which I focus for the remainder of this article.

Sumud or 'steadfastness' is an ethico-political construction of Palestinian collectivity and struggle, signifying at once refusal and endurance of the occupation, clinging to the land in the face of Israeli conditions of active erasure (Halper 2006; Schiocchet 2011). Immanent to struggle in both quotidian and exceptional moments, sumud has a polymorphous quality, though I will focus here on its form as mobilised from the late 1970s to the early 1990s in association with the Popular Front for the Liberation of Palestine (PFLP). Here, sumud pertains especially to conditions of incarceration, interrogation, and torture by the Israel Security Agency, the Shabak, where it designates a refusal to confess and disclose. It is a refusal not arbitrarily chosen but forced by circumstance, insofar as it addresses the 'inevitable predicament' of the colonial encounter, whereby politics can only effectively proceed if it can adequately confront the limit of interrogation, as the embryonic PFLP found to its cost after a first wave of arrests (Meari 2014, p. 561). Intrinsic to this particular task but with cascading ramifications, Meari describes sumud as a 'singular-collective mode of being' through the terms of cramped space that I have been discussing (p. 553). That is to say, it is a 'desubjectiviation' derived from 'continuous engagement with the flows and constraints of the colonial situation that endows Palestinians with forces to endure their lives, through and in opposition to, the fixed colonial terms and relations promoted by the colonizers and those Palestinians constrained by the terms of normalization with them' (pp. 550-1).

Sumud is primarily a technique, or an open set of techniques that further its aim. Sumud seeks to persistently recharge the interrogation encounter with its antagonistic core of colonial social relations, working against the interrogators' efforts to evacuate those relations from the scene. It thus breaks the seduced and forced individualization and privatization that is intrinsic to the structure of interrogation - with its attempted production of self-interest and individual salvation through confession, disclosure, and release. In other words, sumud is a critical embracing of cramped space against the false or apolitical solution of proffered identity. As in the interrogation cell, so in the social realm more broadly, for the enforced individualisation of interrogation has a structural correspondence with the development of Palestinian politics subsequent to the 1993 Oslo Accords under the Palestinian Authority. The post-Oslo condition can be described as the seduction and enforcement of minority autonomy or identity, whereby a Palestinian minority is abstracted from its cramped conditions and bound to the depoliticising or asocial structures of the state, under conditions of extreme deprivation and violence. Here, the Palestinian Authority functions as a client pseudo-state, governing the West Bank in furtherance of Israeli colonial agendas and 'saturated with liberal forms of politics and the process of reproduction of liberal individual sentiments and attachments': the transformation of resistance into the work of nongovernmental organisations, dependent as this is on foreign funding and conditions; the shift from resisting the occupation to establishing Palestinian institutions; the proliferation of discourses of rights and international law; and the adoption of neoliberal development agendas (p. 556; see also Makdisi 2008; Weizman 2007).

Returning to the conditions of incarceration, in this most isolated and individualised of conditions, sumud produces collectivity, but less as a collective subject than a collective 
opening of perception to the pain and antagonism of oppressive social relations. The complex nature of this collectivity is apparent in the words of Ahmad Qatamesh, then a prominent underground leader, who frames sumud as an ethico-political convention 'reached among us out of the conviction that history had positioned us in a particular place that we have to respond to by embracing its burdens' (cited in Meari 2014, p. 564, emphasis added). It is a burden with numerous modalities, which those practicing sumud describe calling upon: the Nakba; the mass incarceration that is intrinsic to Israeli colonial rule; painstakingly told stories of interrogation imparted by those who achieved in sumud and by those who failed; the many deaths under interrogation. It is a willed poverty that mobilises: 'Imagining my death ... for not providing a confession opened my possibilities, not ended them' (Amin, cited in Meari 2014, p. 570).

As the experience of emotional, cognitive, and physical pain that is intrinsic to interrogation would suggest, sumud bears and produces a breakdown of the division between private and political, intimate and social, a breakdown that as we have seen is elemental to cramped minority politics. And this pertains not only to pain, but to a flood of intimate relations and sensibilities into the interrogation scene, as apparent in Riyad's account of his sumud, the texture of which was fashioned with thoughts of his mother, lover, and Palestinian martyrs, without pause between:

During the long interrogation sessions and torture I thought of my sumud as defending my mother and the mothers of others. I was continually thinking about the martyrs and captives and the Palestinians-in-sumud. I thought about the martyr Ibrahim El-Ra'ii and constantly recited songs by the band Sabrin [a Palestinian band that played songs with revolutionary sentiments]. I was in love with a girl and thought that if I practice sumud I would deserve her love. For me, to practice sumud meant to exist (cited in Meari 2014, p. 551).

If the flood of the intimate and the social takes over the isolated individual, sumud at once has a centrifugal quality, as widespread experience of interrogation - since 1967, 800,000 Palestinians in the occupied territories have been detained under military orders - gives families and comrades embodied knowledge of the individual's pain, which is hence collectively born (Addameer 2014). 'I was feeling the pain of the Palestinians enmeshed with my pain', reports Mahmoud: 'I was not confronting the interrogators alone. I was part of all these people and they were part of me' (cited in Meari 2014, p. 574).

Such are the cramped minority conditions of sumud, but what are its specific features and dynamics as a free indirect mediator? Meari argues convincingly that sumud is not an ideology or an abstract idea but an emergent, cultivated, ethico-political process developed across diverse and discontinuous routes and constituencies. Sumud seems to have no origin story as such; its historicity is more one that pertains to the disruption of colonial historical continuity, a destruction that leans into the future of struggle, than it is of historical memory. It is a Palestinian politics, and yet it is derived from a hotchpotch of regional and geopolitical knowledges, literatures, and histories of anticolonial and communist struggle. Dislodged in this way from spatio-temporal continuities, without an established archive, sumud indexes neither an established and coherent Palestinian people, a political organisation, nor particular writers and practitioners, or it does so only imperfectly. Rather, its associations are as much to the open series of its practice and elaboration as it develops new manifestations, significations, and textures of social, intimate, and political life. Like a minor literature with its 'cellar' ever rewritten on the pages of its magazines, Meari describes how the serial elaboration and extension of sumud takes place in critical examination of its 'minute detail', through the obsessive and meticulous recounting of successful and failed experiences, undertaken in 
conversation and in text. These texts are decidedly fragmentary in quality, smuggled out of prison via ingested capsules, circulated in books bound in fake covers which, in the case of Mahmood Fanoon's The Philosophy of Confrontation, never bear the name of their author, a sign at once of necessary secrecy and the collective nature of the struggle of which it speaks. It is readily apparent that in and through these qualities sumud developed the catalytic force of a mediator - it was its raison d'être, to draw the individual away from confession, to intensify and extend Palestinian struggles. It is a capacity that also took sumud beyond the confines of the interrogation, to become a means by which families and comrades projected solidarity back into the interrogation scene - steadfast in the declared knowledge that there would transpire no confession - and drew new substance into struggle across everyday life, as popular song, poetry, the crossing of checkpoints, and techniques of Israeli boycott, all become charged as practices of sumud in the unfurling of its problem.

\section{Conclusion}

Attending, as I have, to one of the most enduring and egregious experiences of oppression in modern times is not to adopt a politics of the very worst. If the proletariat is an open plane of cramped minority conditions and mediators, any particular political site must draw in and push out to other sites and problems in fragmented series - this is the social condition of cramped space, and its peculiar mode of collectivity. It poses problems. How can relations be drawn against the crisis of social reproduction under austerity conditions, with its particular deleterious effects on gender, disability, and racialisation? How can such politics articulate with the passive slaughter of migrants in the passage across the Mediterranean, the intensification of work and creeping unemployment, mundane and militarised racism, and neo-imperialist war and occupation? What mediators will this politics construct? These are open questions for minor politics, which works over the cramped social conditions of any particularity with the knowledge that the answers will not be found in projecting the autonomy of a global subject.

Open Access This article is distributed under the terms of the Creative Commons Attribution 4.0 International License (http://creativecommons.org/licenses/by/4.0/), which permits unrestricted use, distribution, and reproduction in any medium, provided you give appropriate credit to the original author(s) and the source, provide a link to the Creative Commons license, and indicate if changes were made.

\section{References}

Addameer. (2014). Palestinian political prisoners in Israeli prisons. http://www.addameer. org/files/Palestinian\%20Political\%20Prisoners\%20in\%20Israeli\%20Prisons\%20(General\%20Briefing\%20 January\%202014).pdf

Beckett, S. (1979). The Beckett Trilogy: Molloy, Malone dies, the unnamable (Trans. S. Beckett and P. Bowles). trilogy London: Picador.

Dauvé, G. (1997). Leninism and the ultra-left. In G. Dauvé and F. Martin, The eclipse and re-emergence of the communist movement, revised edition. London: Antagonism Press.

Deleuze, G. (1989). Cinema 2: the time-image (Trans. H. Tomlinson and R. Galeta). London: Athlone Press.

Deleuze, G (1995). Negotiations, 1972-1990 (Trans. M. Joughin). New York: Columbia University Press.

Deleuze, G. (1997). Essays critical and clinical (Trans. D. W. Smith and M. A. Greco). Minneapolis: University of Minnesota Press. 
Deleuze, G. and Guattari, F. (1986). Kafka: toward a minor literature (Trans. D. Polan). London: University of Minnesota Press.

Deleuze, G. and Guattari, F. (1988). A thousand plateaus: capitalism and schizophrenia volume 2 (Trans. B. Massumi). London: Athlone Press.

Endnotes. (2008). Afterword. Endnotes, 1, 208.

Endnotes. (2015). Brown v. Ferguson. Endnotes, 4, 10-69.

Endnotes. (n.d.). What are we to do? In Ed. B. Noys. Communization and its discontents: contestation, critique, and contemporary struggles. Wivenhoe: Minor Compositions.

Hallward, P. (2006). Out of this world: Deleuze and the philosophy of creation. London: Verso.

Halper, J. (2006). A strategy within a non-strategy: sumud, resistance, attrition, and advocacy. Journal of Palestine studies, 35(3), 45-51.

Kafka, F. (1999). The diaries of Franz Kafka, 1910-23. Ed. M. Brod. (Trans. J. Kresh and M. Greenberg). London: Penguin.

Makdisi, S. (2008). Palestine inside out: an everyday occupation. New York: W. W. Norton and Co.

Marx, K. (1975a). On the Jewish question. In Early writings (Trans. R. Livingstone and G. Benton). Harmondsworth: Penguin.

Marx, K. (1975b). A contribution to Hegel's philosophy of right. Introduction. In Early writings (Trans. R. Livingstone. and G. Benton). Harmondsworth: Penguin.

Marx, K. and Engels, F. (1974). The German ideology. Ed. C. J. Arthur. London: Lawrence and Wishart.

Marx, K. and Engels, F. (1975). The holy family; or critique of critical criticism. In Collected works, volume 4. London: Lawrence and Wishart.

Meari, L. (2014). Sumud: a Palestinian philosophy of confrontation in colonial prisons. South atlantic quarterly, 113(3), 547-578.

Postone, M. (1996). Time, labor, and social domination: a reinterpretation of Marx's critical theory. Cambridge: Cambridge University Press.

Schiocchet, L. (2011). Palestinian sumud: steadfastness, ritual and the time among Palestinian refugees. Bir Zayt: Birzeit University working paper.

Silva, J. M. (2013). Coming up short: working-class adulthood in an age of uncertainty. Oxford: Oxford University Press.

Thatcher, M. (1987) Interview for Woman's Own. 23 September, http://www.margaretthatcher. org/document/106689.

The Free Association. (2005). Event horizon. Ephemera: theory and politics in organization, 5(4), 568-579.

Théorie Communiste. (2006). Self-organisation is the first act of the revolution; it then becomes an obstacle which the revolution has to overcome. Paris: Théorie Communiste.

Théorie Communiste. (2008). Much ado about nothing. Endnotes, 1, 154-206.

Thoburn, N. (2003). Deleuze, Marx and politics. London and New York: Routledge.

Weizman, E. (2007). Hollow land: Israel's architecture of occupation. London: Verso.

Wilderson, F. B. (2003). Gramsci's black Marx: whither the slave in civil society? Social Identities, 9(2), 225-240. 